\title{
Effect of feeding program during rearing and age at first insemination on performances during subsequent reproduction in young rabbit does
}

\author{
Jorine M. ROMMERS ${ }^{\mathrm{a} *}$, Ron MEIJERHOF ${ }^{\mathrm{b}}$, \\ Jos P.T.M. NOORDHUIZEN ${ }^{\mathrm{c}}$, Bas KEMP ${ }^{\mathrm{d}}$ \\ ${ }^{a}$ Animal Sciences Group (ASG) of Wageningen University and Research Centre, Applied Research, \\ PO Box 2176, 8203 AD Lelystad, The Netherlands \\ ${ }^{b}$ Hybro, PO Box 30, 5830 AA Boxmeer, The Netherlands \\ ${ }^{c}$ Department of Farm Animal Health, Faculty of Veterinary Medicine, University of Utrecht, \\ PO Box 80151, 3508 TD Utrecht, The Netherlands \\ $\mathrm{d}$ Animal Sciences Group of Wageningen University and Research Centre, \\ Department of Animal Sciences, Marijkeweg 40, 6700 AH Wageningen, The Netherlands
}

(Received 11 November 2003; accepted 17 March 2004)

\begin{abstract}
An experiment was performed to study the effect of the feeding program and age at first mating on body growth, feed intake, reproductive performance, and culling of rabbit does over three parities, using 155 does of a strain of New Zealand white rabbits. Three treatments were applied. Ad libitum feeding until first insemination at $14.5 \mathrm{wk}$ (AL-14.5) or 17.5 wk of age (AL-17.5), and restrictive feeding from five wk of age until first insemination at $17.5 \mathrm{wk}$ of age (R-17.5). At first insemination, the BW of AL-14.5 and R-17.5 was similar (3907 vs. $3791 \pm 46 \mathrm{~g}$, respectively), whereas AL-17.5 does were heavier $(4390 \pm 46 \mathrm{~g}, P<0.001)$. During reproduction, performance of AL-17.5 was not improved compared to AL-14.5 and R-17.5 does. Al-17.5 does showed a lower feed intake during the first gestation $(-25 \%)$ and first parity $(-10 \%)$ than R-17.5, resulting in weight loss $(-6 \%)$ during the first gestation and decreased litter weights $(-19 \%)$ and litter growth $(-14 \%)$ in the first parity. Extended first mating by three wk (17.5 vs. $14.5 \mathrm{wk})$ but similar BW at first mating did not affect feed intake and BW development during the first three parities. However, the number of live born kits and weight at first kindling, and litter growth in the first parity were improved in R-17.5 ( $+23 \%,+18 \%$, and $+14 \%$, respectively). Reproductive performance can be improved by restricted feeding during rearing and extended first insemination to $17.5 \mathrm{wk}$ of age. However, the culling rate was not affected by the rearing strategy.
\end{abstract}

rabbit / rearing techniques / reproduction

\section{INTRODUCTION}

In commercial rabbit production, does suffer from a severe loss of body energy during the first lactation, resulting in a decreased reproductive performance and a high replacement rate of young does [1]. Management measures during lactation do not adequately solve the problem of negative energy balance. So other solutions are recommended [2-4].

Body condition at first insemination may affect the problem of a negative energy balance during rearing. Does that are well

\footnotetext{
* Corresponding author: Jorine.Rommers1@wur.nl
} 
developed and more matured at first insemination could be more capable to cope with the forenamed problems. Body development at first insemination can be influenced by feed intake during rearing and the age of first insemination [5].

Under practical conditions, rabbit does are often fed ad libitum during rearing until first mating. First mating is recommended when 75 to $80 \%$ of mature BW is reached [6]. However, BW might not be a good indicator and does may be immature at first mating although desired BW is reached, resulting in poor pregnancy rates or decreased reproductive performance [5, 7]. Delaying first mating to an older age could be favourable to obtain a more matured young doe. However, these young does will be heavier with the risk of excessive fat deposition [8] that might cause health problems or decrease reproductive performance. Restrictive feeding during rearing can be used to control $\mathrm{BW}$ and prevent overfattening.

The effect of extending age at first mating with or without feed restriction during rearing on subsequent performances has never been studied in detail. Rommers et al. [5] studied the effect of BW and age at first mating on body growth, body composition, and sexual development at the end of rearing. With a restrictive feeding regime, it was possible to obtain does which differed three wk in age at first insemination, but had similar BW, body composition, and sexual development. Under ad libitum feeding conditions, older does were heavier, contained more fat, but had the best sexual development, in terms of receptivity, number of corpera lutea, and recovery rate, compared to younger does. However, information of these rearing strategies on subsequent reproduction is not known. Therefore, an experiment was performed to study the relation between BW and age at first insemination on body weight development, feed intake, reproductive performance and culling in the first three parities.

\section{MATERIALS AND METHODS}

The experiment was performed from October 2001 to September 2002. The Use and Care Committee of the Research Institute of Animal Husbandry approved all protocols. The experiment was performed with 155 does of a strain of New Zealand White rabbit does, bred at ASG, Applied Research. The does were housed in identical compartments in individual cages $(50 \times 60 \times 30 \mathrm{~cm})$ of galvanised wire net, equipped with an automatic drinker and a manual feeder. The experiment started when the does were $30 \mathrm{~d}$ of age and ended at the weaning of their third litter.

\subsection{Rearing period}

To obtain animals for this experiment, kits were raised in litters of nine kits. Litter size was kept at nine kits during the preweaning period as described in Rommers [9]. At the start of the experiment ( $30 \mathrm{~d}$ of age), from each litter three female kits (full sisters), with live weight deviating by less than $15 \%$ of the average litter weight, were selected. Each group of three sisters was taken, moved to another compartment and put into three adjacent individual cages. The sisters were assigned to one of the three treatments. The does were submitted to a photoperiod of $12 \mathrm{~h}$. The first two wk after weaning, a minimum ambient temperature of $18^{\circ} \mathrm{C}$ was maintained. From two wk after weaning onwards, the minimum ambient temperature was set at $16^{\circ} \mathrm{C}$. The does were fed a standard commercial diet, containing $10.3 \mathrm{MJ} \cdot \mathrm{kg}^{-1} \mathrm{ME}$ and $170 \mathrm{~g} \cdot \mathrm{kg}^{-1}$ crude protein (ABCTA, Lochem, The Netherlands) and were fed according to a treatment regime until five $d$ prior to first insemination. From five $d$ prior to insemination onwards all treatment groups were fed the standard diet to appetite to stimulate receptivity (flushing). 


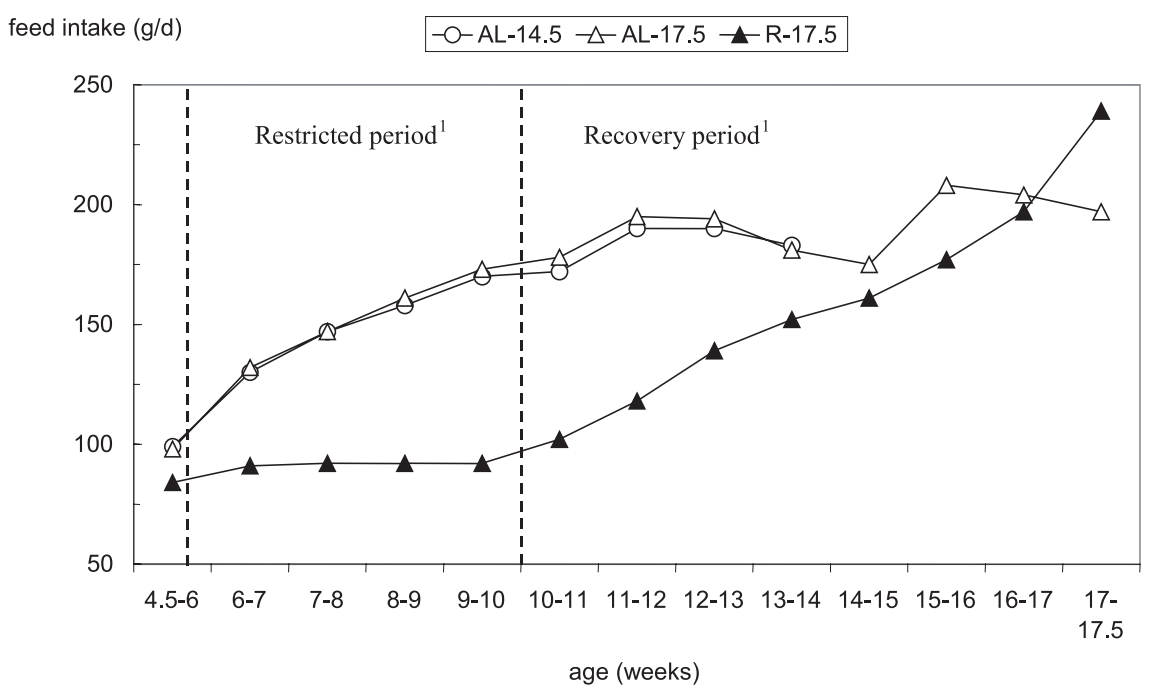

Figure 1. Average feed intake for ad libitum (AL) and restrictive (R) fed does during rearing from weaning $(4.5 \mathrm{wk})$ to first insemination at 14.5 or $17.5 \mathrm{wk}$ of age. ${ }^{1}$ See Materials and methods.

\subsection{Treatments}

The treatments started at five wk of age. Three treatments were applied. The animals belonging to our institute line reached $80 \%$ of their mature BW around $14.5 \mathrm{wk}$ of age under ad libitum feeding conditions. Therefore, ad libitum feeding and first insemination at $14.5 \mathrm{wk}$ of age (AL-14.5) was used as the control. The rearing period was extended by three weeks under ad libitum feeding (AL-17.5) or restrictive feeding (R-17.5). The purpose of the restrictive feeding regime was to postpone the age of first mating by three wk of age, but reaching the same BW as AL does at $14.5 \mathrm{wk}$ of age.

To prevent overfattening and to stimulate sexual development, which starts around 10 to 12 wk of age [10], the restrictive feeding regime was as follows:

(1) Restricted period (5 to 10 wk of age), in which body growth was delayed by progressively reducing feed intake from $85 \%$ at $6 \mathrm{wk}$ of age to $54 \%$ of $\mathrm{AL}$ at $10 \mathrm{wk}$ of age. In this period mainly protein development is hindered.
(2) Recovery period (from $10 \mathrm{wk}$ to first insemination). Feed intake was gradually increased to $120 \%$ of $\mathrm{AL}$ during the last five $\mathrm{d}$ before insemination (Fig. 1). Young does will first compensate for the loss in protein and thereby excessive fat deposition will be extended [11].

At 17.5 wk of age, the restrictive fed animals reached the same BW as AL-14.5 (Fig. 2).

From the data of a previous experiment [9], the BW curve for ad libitum fed does was fitted (Fig. 2). The BW of the restricted fed does was derived from this curve following the feeding strategy as described in the previous paragraph. The restrictive fed does were fed a restricted amount of feed daily, aiming to follow the BW curve as shown in Figure 2. Therefore, BW was determined weekly from weaning until $10 \mathrm{wk}$ of age and twice weekly from $10 \mathrm{wk}$ of age to first insemination. Feed intake was corrected after each time the does were weighed in order to follow the fixed BW curve. If the daily supply was not eaten completely, remaining feed was removed. 


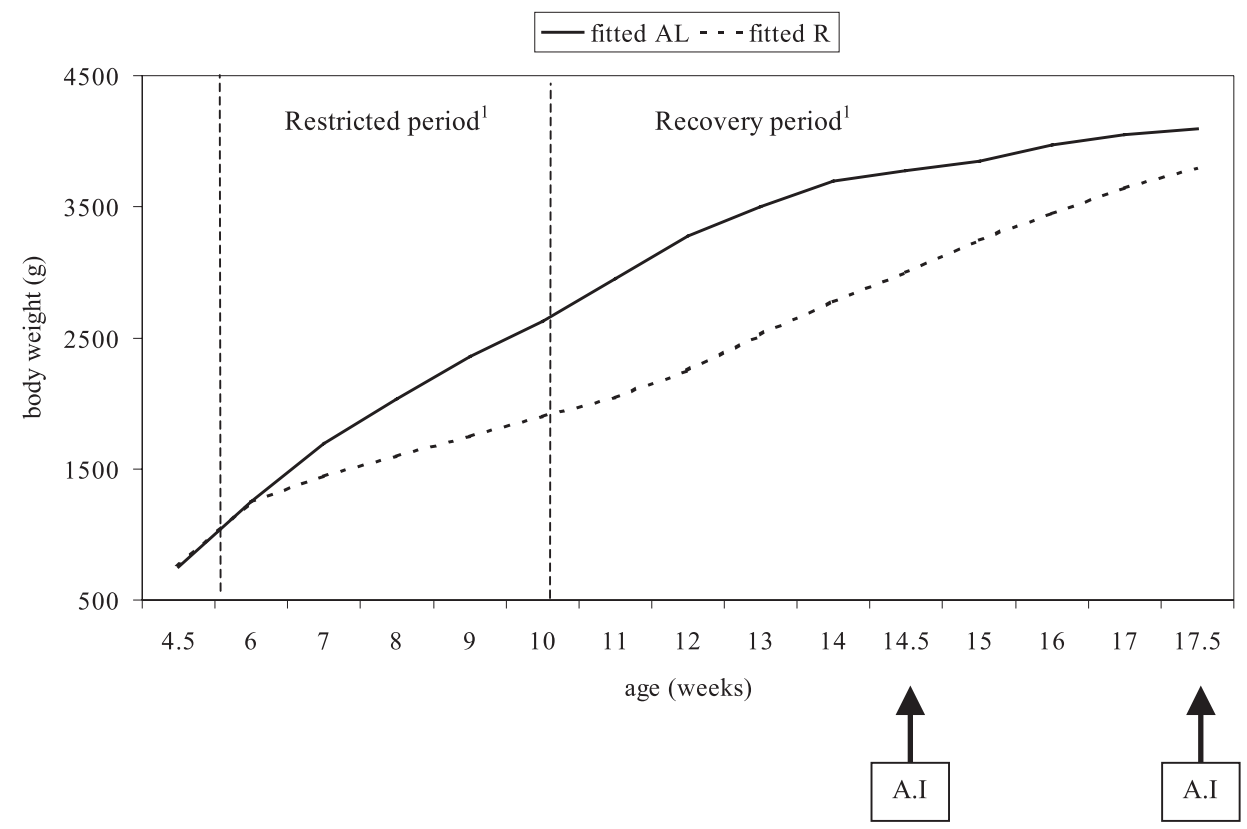

Figure 2. Fixed body weight curve for the ad libitum (AL) and restrictive (R) feeding during rearing from weaning ( $4.5 \mathrm{wk}$ of age) to first insemination at 14.5 or $17.5 \mathrm{wk}$ of age. ${ }^{1}$ See Materials and methods.

\subsection{Reproductive period}

From 17.5 wk of age onwards, the photoperiod was set at $16 \mathrm{~h}$. Photoperiod was prolonged after the first inseminations at 17.5 wk of age occurred. In this way, receptivity was not stimulated in any of the treatments. The does fed ad libitum the same commercial standard diet as during rearing. The does were inseminated 10 to $12 \mathrm{~d}$ postpartum. Artificial insemination was performed with fresh mixed semen of 10 bucks, selected for growth performance. At the day of insemination, one mixed and diluted semen dose was prepared. Dilution was performed using a commercial extender (Galap, IMV, France) according to the method developed by Zöldág et al. [12]. A GnRH analogue was injected i.m. (0.2 mL Receptal, Hoechst Roussel Vet, Brussels) immediately after insemination to induce ovulation. Non-pregnant does were inseminated three wk after the first insemination. Does not pregnant after two successive inseminations were excluded from the experiment.

Nestboxes $(30 \times 25 \times 30 \mathrm{~cm})$ were attached to the front sides of the cages five $d$ prior to kindling and were removed at $21 \mathrm{~d}$ of lactation. At the first day after kindling litter size was standardised by cross fostering of kits within a treatment. In the first parity, litter size was standardised at eight kits, in the second and third parity it was set at nine kits. The kits were weaned at $30 \mathrm{~d}$ of lactation.

\subsection{Measurements}

\subsubsection{Body weight}

The does were weighed individually once every week from weaning to $10 \mathrm{wk}$ of age and twice weekly until first insemination. During the first gestation, the does 
were weighed weekly. After kindling, the does were weighed at $16 \mathrm{~d}$, and $30 \mathrm{~d}$ of lactation in the first three parities.

\subsubsection{Feed intake}

During rearing, feed intake was determined individually weekly from weaning to $10 \mathrm{wk}$ of age and twice weekly until first insemination by weighing of the feeder at the beginning and end of each week and the weight of all feed supplies given in between were recorded. For the R-17.5 does, the amount of feed not eaten per day was weighed weekly to determine the actual feed intake. If wastage occurred, the week number and cage were recorded, and feed intake was scored as the missing value. During the first gestation, feed intake was determined weekly. After first kindling feed intake was determined for the following periods in the first three parities: from kindling to $\mathrm{d} 16$ of lactation, from d 16 to $\mathrm{d} 30$ of lactation, and from d 30 of lactation to subsequent kindling.

\subsubsection{Reproductive performance}

Kindling rate was calculated as the number of does that kindled after the first insemination divided by the number of first inseminations. The number of live and stillborn kits (total litter size), the number of kits at $16 \mathrm{~d}$ and $30 \mathrm{~d}$ of lactation, together with the litter weight at $16 \mathrm{~d}$, and $30 \mathrm{~d}$ were recorded. The average kit weight at $16 \mathrm{~d}$ was used as an estimate for milk production, because in our system we observe that kits start eating solid feed from $17 \mathrm{~d}$ onwards (personal observation).

\subsubsection{Culling}

The number of does culled and the reason for culling was recorded. Dissections were performed on dead and euthanasised diseased does.

\subsection{Statistical analyses}

The experimental design was a randomised block. A block consisted of three adjacent cages housing sisters. The three treatments were randomly assigned to the cages within a block. Analyses of variance were carried out using the GLM procedure of SAS (SAS Inst. Inc., Cary, NC, USA). All data are presented as LS means and standard errors.

\subsubsection{Rearing period}

Data of all the does were used for analyses. Body weight, feed intake, and feed efficiency were analysed for the total rearing period. Differences among treatments were tested using the following model: $Y_{i j}=\mu+B_{i}+T_{j}+(B x T)_{i j}+e_{i j}[$ model 1] where $Y_{i j}$ is the dependent variable; $\mu=$ overall mean; $\mathrm{B}_{\mathrm{i}}=$ block, three adjacent cages with sisters; $T_{j}=$ treatment AL-14.5, AL-17.5, and R-17.5; $\mathrm{BxT}_{\mathrm{ij}}=$ interaction between block and treatment; and $\mathrm{e}_{\mathrm{ij}}$ is the residual error. Differences between LSM were analysed by the PDIFF option of the GLM procedures of SAS. In all analyses, non-significant interactions were deleted from the model.

\subsubsection{Reproductive period}

In the first parity, data were used from does that kindled after the first insemination. In the second and third parity, does were used that kindled after the first insemination 10 to $12 \mathrm{~d}$ postpartum. Only the data of does, pregnant after first inseminations were taken, because these does did not compensate for body energy balance, which did occur in the does with extended first insemination. The blocks became unbalanced because of the exclusion of culling and nonpregnant does. Therefore, the block was excluded from model 1. Differences in kindling rate and percentage of stillborn kits among treatments were analysed with a chisquared test.

Culling rate of does during the first three parities. Data of all does in the experiment were used for analyses of culling rate. Differences in the culling rate among treatments were analysed with a chi-squared test. 
Table I. Body weight, body growth, feed intake and gain to feed ratio during rearing from $30 \mathrm{~d}$ of age to first insemination at 14.5 or $17.5 \mathrm{wk}$ of age for does fed ad libitum (AL) or restrictive (R).

\begin{tabular}{lccccc}
\hline Treatment & AL-14.5 & AL-17.5 & R-17.5 & SEM & $P$-value \\
\hline Does, No. & 52 & 51 & 52 & & \\
BW at start (30 d of age), g & 741 & 743 & 740 & 4.6 & NS \\
Body growth, $g \cdot d^{-1}$ & $42.5^{\mathrm{a}}$ & $39.2^{\mathrm{b}}$ & $34.0^{\mathrm{c}}$ & 0.4 & 0.001 \\
Feed intake, $\mathrm{g} \cdot \mathrm{d}^{-1}$ & $159^{\mathrm{a}}$ & $166^{\mathrm{a}}$ & $128^{\mathrm{b}}$ & 2.1 & 0.001 \\
Gain to feed ratio & $0.27^{\mathrm{a}}$ & $0.27^{\mathrm{a}}$ & $0.23^{\mathrm{b}}$ & 0.03 & 0.001 \\
BW at first insemination, $\mathrm{g}$ & $3791^{\mathrm{a}}$ & $4390^{\mathrm{b}}$ & $3910^{\mathrm{a}}$ & 35.8 & 0.001 \\
\hline
\end{tabular}

a,b Means with different letter in a row differ significantly.

\section{RESULTS}

\subsection{Animals and culling}

The experiment started with $52,51,52$ does for AL-14.5, AL-17.5, and R-17.5, respectively. During the rearing period four does with diarrhoea were removed (1 from $\mathrm{AL}-14.5$, and 3 from $\mathrm{AL}-17.5$, respectively). At dissection, no further abnormalities were found.

During the reproductive period, there was no difference in culling rate among treatments $(27.5,25.0$, and $21.2 \%$ for AL14.5, AL-17.5, and R-17.5, respectively). Eighty percent of all the culling occurred in the first two parities. Culling was caused by several reasons, such as reproductive failure, dystocia, digestive disorder, Pasteurella multocida, and fatty liver. Culling after weaning was due to feet injuries, metritis, and mastitis.

\subsection{Body weight, feed intake, and gain/feed ratio during rearing}

In Table I, the performance during the rearing period is presented. At the start of the experiment, there was no difference among treatments in BW. At the end of rearing, AL-17.5 was heavier than AL-14.5 and R-17.5 $(P<0.001)$. BW of AL-14.5 and $\mathrm{R}-17.5$ were comparable. The feed to gain ratio over the total rearing period was equal for AL-14.5 and R-17.5, whereas the feed to gain ratio of AL-17.5 was lower $(P<$ 0.001).

In Figure 3, body growth during rearing is presented. From 10 wk of age onwards, growth rate of AL-does gradually decreased. The growth rate of $\mathrm{R}$ does was hindered in the restricted period, whereas in the recovery period growth rate increased. Restrictive fed does showed a growth spurt during the last five $\mathrm{d}$ before insemination, in which the does were flushed.

\subsection{Body weight, body growth and feed intake during reproduction}

Body weight for the successive reproductive periods is presented in Figure 4. AL-17.5 does were heavier at first insemination (4 356 $\pm 48 ; P<0.001)$ and remained so during the reproductive period. AL-14.5 and R-17.5 does were smaller at first insemination (3991 \pm 46 and $3933 \pm 45$, respectively) than the AL-17.5 does, but part of the difference was compensated for during the first gestation period. Body weight gain from first insemination to first kindling was $106,-260$, and $41 \pm 40 \mathrm{~g}$ for AL-14.5, AL-17.5, and R-17.5, respectively $(P<0.001)$. After the first kindling, body growth among the treatment was comparable. Based on the does that kindled after every first insemination until the third parity, body weight gain over the three parities was $498 \pm 83,174 \pm 83$, 


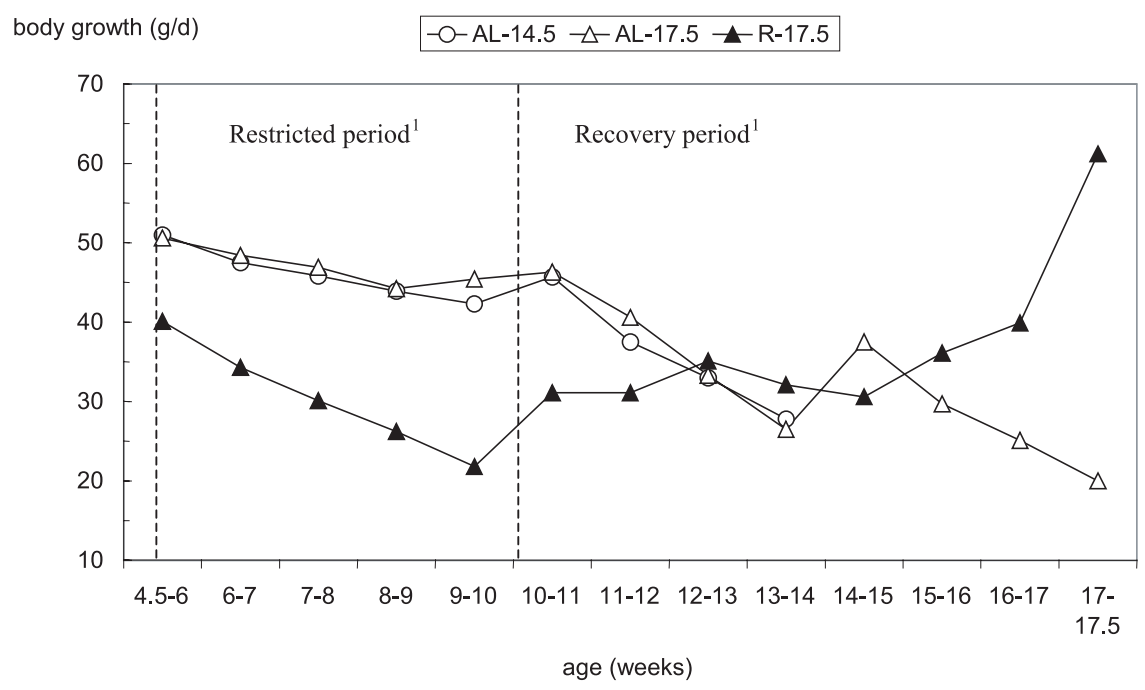

Figure 3. Average body growth for ad libitum (AL) and restrictive (R) fed does during rearing from weaning $(4.5 \mathrm{wk})$ to first insemination at 14.5 or $17.5 \mathrm{wk}$ of age. ${ }^{1}$ See Materials and methods.

and $333 \pm 80 \mathrm{~g}$ for AL-14.5, AL-17.5, and R-17.5, respectively. AL-14.5 had the highest body weight gain, AL-17.5 had the lowest body weight gain $(P<0.05)$, whereas a body weight gain of R-17.5 was intermediate.

Feed intake during reproduction is given in Table II. In the first gestation and lactation period AL-17.5 does consumed less feed than AL-14.5 and R-17.5 $(P<0.05)$. In the weaning to kindling interval of the second parity, AL-17.5 consumed more feed than AL-14.5 $(P<0.05)$, whereas R-17.5 was intermediate. In the third lactation, there were no differences in feed intake among treatments.

\subsection{Reproductive performances.}

Reproductive performance is presented in Table III. Due to small numbers of live born kits, kits of litters with three or less kits were removed and used for cross fostering (in total 7, 12, and 16 for AL-14.5, AL-17.5, and R-17.5, respectively). During the reproductive period, there was no difference in kindling rate among treatments. In the first parity, R-17.5 does produced more live born kits than AL-14.5 and AL-17.5. In the second and third parity, there was no difference in litter size among treatments. The kits of R-17.5 does were heavier at d 16 of lactation in all parities, which indicates that does produced more milk and resulted in heavier kits at weaning in the first two parities.

\section{DISCUSSION}

Rabbit does are susceptible to a severe energy deficit during first lactation [1], resulting in a decreased reproductive performance and high replacement rate. Our hypothesis was that does fed ad libitum and inseminated at $17.5 \mathrm{wk}$ of age are more matured and have more body reserves (protein and fat tissue) which enable them to better resist to the energy deficit during first lactation, resulting in a better performance and/or decreased culling.

The effect of extra BW at first insemination is demonstrated by comparing AL-17.5 


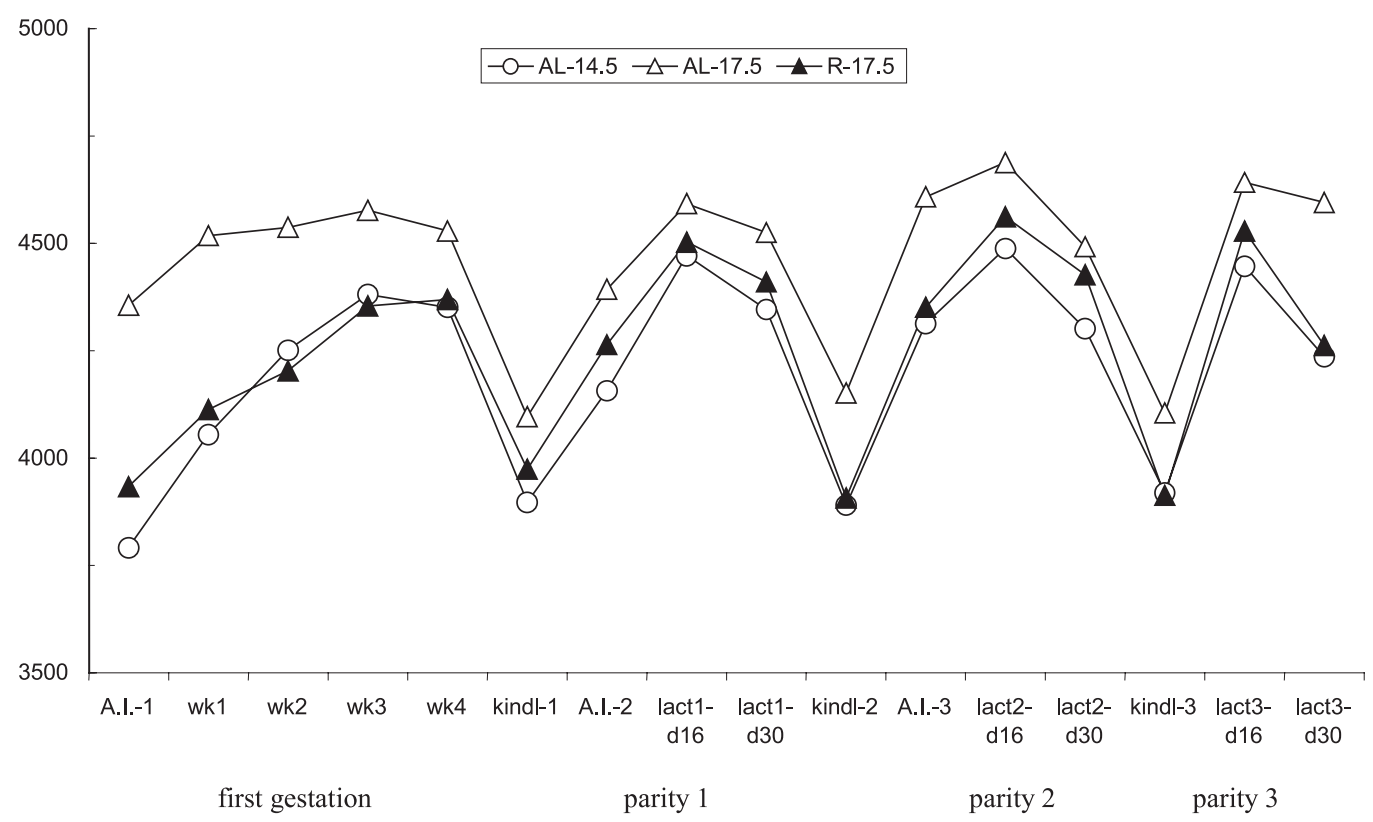

Figure 4. Average BW for ad libitum (AL) and restrictive (R) fed does during the reproductive period for does pregnant after first insemination (14.5 or $17.5 \mathrm{wk}$ of age, 10 to $12 \mathrm{~d}$ postpartum). 
Table II. Feed intake $\left(\mathrm{g} \cdot \mathrm{d}^{-1}\right)$ during different stages of reproduction for does that kindled after first inseminations at 14.5 or $17.5 \mathrm{wk}$ of age and 10 to $12 \mathrm{~d}$ postpartum.

\begin{tabular}{|c|c|c|c|c|c|}
\hline Treatment $^{1}$ & AL-14.5 & AL-17.5 & $\mathrm{R}-17.5$ & SEM & $P$-value \\
\hline Item, $g \cdot d^{-1}$ & \multicolumn{5}{|c|}{ First gestation ---------------- } \\
\hline Does, No. & 51 & 48 & 52 & & \\
\hline Gestation, week 1 & $215^{\mathrm{a}}$ & $206^{\mathrm{a}}$ & $236^{\mathrm{b}}$ & 5 & 0.001 \\
\hline Gestation, week 2 & $207^{\mathrm{a}}$ & $159^{\mathrm{b}}$ & $189^{\mathrm{a}}$ & 6 & 0.001 \\
\hline Gestation, week 3 & $184^{\mathrm{a}}$ & $135^{\mathrm{b}}$ & $189^{\mathrm{a}}$ & 6 & 0.001 \\
\hline Gestation, week 4 & $112^{\mathrm{a}}$ & $85^{\mathrm{b}}$ & $114^{\mathrm{a}}$ & 5 & 0.001 \\
\hline Gestation, d 28 until d 32 & $79^{\mathrm{ab}}$ & $69^{\mathrm{a}}$ & $99^{\mathrm{b}}$ & 9 & 0.01 \\
\hline \multirow[t]{2}{*}{ Avg in gestation period ( $32 \mathrm{~d}$ ) } & $167^{\mathrm{a}}$ & $137^{\mathrm{b}}$ & $172^{\mathrm{a}}$ & 3 & 0.001 \\
\hline & 43 & $\begin{array}{c}\text { First parity } \\
40\end{array}$ & - n & & \\
\hline $\begin{array}{l}\text { From kindling to } \mathrm{d} 16 \\
\text { of lactation }\end{array}$ & $302^{\mathrm{a}}$ & $237^{b}$ & $274^{\mathrm{c}}$ & 8 & 0.001 \\
\hline From d 16 to $\mathrm{d} 30$ of lactation & $460^{\mathrm{a}}$ & $454^{\mathrm{a}}$ & $491^{\mathrm{b}}$ & 9 & 0.05 \\
\hline Avg in first lactation $(30 \mathrm{~d})$ & $376^{\mathrm{a}}$ & $338^{\mathrm{b}}$ & $375^{\mathrm{a}}$ & 8 & 0.01 \\
\hline \multirow{2}{*}{$\begin{array}{l}\text { From weaning }(\mathrm{d} 30) \text { to kindling } \\
(12 \mathrm{~d})\end{array}$} & $160^{\mathrm{a}}$ & $181^{\mathrm{b}}$ & $176^{\mathrm{ab}}$ & 6 & 0.05 \\
\hline & ----- & \multicolumn{2}{|c|}{ Second parity ---------- } & & \\
\hline Does, No. & 26 & 25 & 32 & & \\
\hline Avg in second lactation (30 d) & 456 & 448 & 461 & 10 & 0.69 \\
\hline \multirow{2}{*}{$\begin{array}{l}\text { From weaning (d30) to kindling } \\
\text { (12 d) }\end{array}$} & 183 & 199 & 197 & 7 & 0.23 \\
\hline & - & Third parity & ----- & & \\
\hline Does, No. & 16 & 16 & 20 & & \\
\hline Avg in third lactation $(30 \mathrm{~d})$ & 445 & 464 & 466 & 11 & 0.38 \\
\hline
\end{tabular}

and R-17.5 does. Ad libitum fed does are heavier. In a previous study, it was shown that the empty body of these does contained more protein and fat tissue and that the best puberty characteristics were obtained compared to restrictive fed does at the same age [5]. The better puberty characteristics (in terms of receptivity, number of corpora lutea, number of embryos and embryo recovery rate) that were found at the end of rearing might be counteracted by the lower feed intake and weight loss during the first ges- tation. During the first gestation of AL-17.5 does, feed intake was $25 \%$ lower, does lost $6 \%$ of their initial BW at first mating and litter weight at kindling was $19 \%$ lower compared to R-17.5 does. Feed intake was still lower in the first parity in Al-17.5 compared with R-17.5 does and kit weight at weaning was decreased, presumably due to a lower milk production. The lower feed intake could be explained by the higher fat content of these does at first insemination. When the mass of adipose tissue increases, insulin 
Table III. Reproductive performance for does which kindled after first insemination at 14.5 or $17.5 \mathrm{wk}$ of age and 10 to $12 \mathrm{~d}$ postpartum.

\begin{tabular}{|c|c|c|c|c|c|}
\hline Treatment $^{1}$ & AL-14.5 & AL-17.5 & $\mathrm{R}-17.5$ & SEM & $P$-value \\
\hline Item & ---------- & \multicolumn{2}{|c|}{ First parity } & & \\
\hline Does, No. & 43 & 40 & 44 & & \\
\hline Kindling rate, $\%$ & 84.3 & 83.3 & 84.6 & & $0.95^{3}$ \\
\hline Total born, No. & 7.0 & 6.5 & 7.7 & 0.4 & 0.1 \\
\hline Born alive, No. & $6.1^{\mathrm{a}}$ & $6.1^{\mathrm{a}}$ & $7.5^{\mathrm{b}}$ & 0.4 & 0.02 \\
\hline Stillborn, \% & 13.5 & 6.5 & 2.3 & & $0.15^{3}$ \\
\hline Kits weaned, No. ${ }^{1}$ & $7.2^{\mathrm{a}}$ & $7.5^{\mathrm{ab}}$ & $7.8^{\mathrm{b}}$ & 0.2 & 0.03 \\
\hline Avg kit wt at $\mathrm{d} 16, \mathrm{~g}$ & $251^{\mathrm{ab}}$ & $242^{\mathrm{a}}$ & $271^{\mathrm{b}}$ & 7 & 0.01 \\
\hline Avg kit wt at weaning (d 30), $g$ & $713^{\mathrm{ab}}$ & $683^{\mathrm{a}}$ & $741^{b}$ & 14 & 0.02 \\
\hline Does, No. & 26 & \multicolumn{2}{|c|}{ Second parity } & & \\
\hline Kindling rate, $\%$ & 72.2 & 89.3 & 78.0 & & $0.21^{3}$ \\
\hline Total born, No. & 9.4 & 9.4 & 9.8 & 0.5 & 0.84 \\
\hline Born alive, No. & 8.8 & 8.8 & 9 & 0.6 & 0.96 \\
\hline Stillborn, \% & 6.8 & 6.4 & 8.1 & & $0.11^{3}$ \\
\hline Kits weaned, No. ${ }^{2}$ & 8.6 & 8.6 & 7.8 & 0.3 & 0.08 \\
\hline Avg kit wt at d 16, g & $303^{\mathrm{a}}$ & $300^{\mathrm{a}}$ & $346^{\mathrm{b}}$ & 7 & 0.001 \\
\hline \multirow[t]{2}{*}{ Avg kit wt at weaning (d 30), g } & $793^{\mathrm{a}}$ & $793^{\mathrm{a}}$ & $856^{\mathrm{b}}$ & 16 & 0.01 \\
\hline & & \multicolumn{2}{|c|}{ Third parity } & & \\
\hline Does, No. & 16 & 16 & 20 & & \\
\hline Kindling rate, $\%$ & 66.7 & 76.2 & 74.1 & & $0.75^{3}$ \\
\hline Total born, No. & 9.8 & 9.0 & 10 & 0.6 & 0.44 \\
\hline Born alive, No. & 8.9 & 8.8 & 8.9 & 0.8 & 0.99 \\
\hline Stillborn, \% & 9.0 & 2.1 & 11.5 & & $0.09^{3}$ \\
\hline Kits weaned, No. ${ }^{2}$ & 8.8 & 8.7 & 8.9 & 0.1 & 0.61 \\
\hline Kit wt at $\mathrm{d} 16, \mathrm{~g}$ & $306^{\mathrm{a}}$ & $306^{\mathrm{a}}$ & $331^{\mathrm{b}}$ & 7 & 0.02 \\
\hline Kit wt at weaning (d 30), g & 775 & 756 & 785 & 24 & 0.68 \\
\hline
\end{tabular}

${ }^{1}$ Does were fed ad libitum (AL) or restrictive (R) during rearing and inseminated at 14.5 or $17.5 \mathrm{wk}$ of age.

${ }^{2}$ Litter size standardised at first day after kindling; first parity at eight kits, second and third parity at nine kits.

${ }^{3}$ Chi-square test.

a,b Means with a different letter in a row differ significantly.

insensitivity can develop. In pigs, it has been shown that fat animals at the end of pregnancy and early lactation are insulin resistant, resulting in higher glucose concentration in blood plasma, which may explain the observed reduction in voluntary feed intake [13]. The reduced feed intake in does, which have more fat, could also be explained by the secretion of leptin by the fat cells. Recent studies in pigs and bovines 
have demonstrated that leptin is an important regulator of feed intake $[14,15]$. In rabbit does, this phenomenon has not been studied to the knowledge of the authors. Based on these results, it can be concluded that AL-17.5 does did not benefit from either the extra amount of BW or the older age at first mating.

Restrictive feeding can be used to control body growth and prevent excessive fat deposition. Restrictive fed does mated at 17.5 wk of age had similar BW. In a previous experiment, in which a similar feeding strategy was applied, R-17.5 and AL-14.5 does had similar body composition at first insemination [5]. Older age at first mating and similar BW improved litter weight and litter growth in the first parity. The better reproductive performance of R-17.5 does can not be explained by differences in feed intake or body growth compared to AL14.5. However, it could be that priority is shifted towards reproduction when first insemination is extended to an older age.

Neither age nor BW at first mating affected the culling rate of does during reproduction. On average, $25 \%$ of the does were culled during the first three parities. Although AL14.5 and R-17.5 does had a higher feed intake during first gestation and first parity compared to AL-17.5 does, BW development during reproduction was similar for all treatments. This could explain why culling rate was not affected.

\section{IMPLICATIONS}

The results of this study indicate the following:

(a) An increasing age at first insemination under ad libitum feeding is not useful (no increase in reproductive performance) and reduces feed intake during first pregnancy and first lactation (no apparent advantage on body energy deficit).

(b) An increasing age at first insemination under restricted feeding did not modify feed behaviour (no apparent advantage on body energy deficit) but increased reproductive performance (prolificacy and kit weight at weaning during the first kindling and lactation).

(c) An culling rate of does during the first three parities of reproduction was not affected by the rearing method.

(d) It may be questioned whether the little increase of reproductive efficiency at first kindling outweighs the longer rearing period and the technical difficulty of restricted feeding.

\section{ACKNOWLEDGEMENTS}

The authors thank Paul Harmelink, Hans van Schaik, and Sander van Voorst for their help during the experiment.

\section{REFERENCES}

[1] Xiccato G. Nutrition of lactating does. In: 6th World Rabbit Congress, 1996, 1: 29-47.

[2] Cervera C, Fernandez-Carmona J, Viudes P, Blas E. Effect of re-mating interval and diet on the performances of female rabbits and their litters. Anim Prod 1993, 56: 399-405.

[3] Xiccato G, Parigi-Bini R, DalleZotte A, Carazollo A, Cossu M E. Effect of dietary energy level, addition of fat and physiological state on performance and energy balance of lactating pregnant rabbit does. Anim Sci 1995, 61: 387398.

[4] Parigi-Bini R, Xiccato G, Dalle Zotte A, Carazollo A, Castellini C, Stradaioli G. Effect of remating interval and diet on the performance and energy balance of rabbit does. In: 6th World Rabbit Congress, 1996, 1: 253-258.

[5] Rommers JM, Meijerhof R, Noordhuizen JPTM, Kemp B. Effect of different feeding levels during rearing and age of first inseminations on body development, body composition, and puberty characteristics of rabbit does. World Rabbit Science 2001, 9: 101108.

[6] Lebas F, Coudert P, Rouvier R, De Rochambeau $H$. The rabbit. Husbandry, health and production. FAO Animal Production and Health Series No 21, Rome, 1986. 
[7] Lebas F, Coudert P. Effet de l'âge des lapines Néozélandaises et Californiennes lors de la première saillie sur leur production et leur devenir : résultats préliminaires. In: 3rd World Rabbit Congress, 1984, 3: 223-225.

[8] Deltoro J, Lopez AM. Allometric changes during growth in rabbits. J Agr Sci Camb 1985, 105: 339-346.

[9] Rommers JM, Kemp B, Meijerhof R, Noordhuizen JPTM. The effect of litter size before weaning on subsequent body development, feed intake, and reproductive performance of young rabbit does. J Anim Sci 2001, 79: 1973-1982.

[10] Ouhayoun J. La croissance et le développement du lapin de chair. Cuni Sciences 1984, 1: 1-15.

[11] Ledin I. Effect of restricted feeding and realimentation on compensatory growth, carcass composition and organ growth in rabbit. Ann Zootech 1984, 33: 33-50.

[12] Zöldág L, Gábor Gy, Sinkovics Gy. A rapid semen evaluation method and efficacy of artificial insemination in angora breeding stocks. Magyar Allatorvosok Lapja 1988, 43: 517519.

[13] Revell DK, Williams IH. A Review - Physiological control and manipulation of voluntary food intake. in: Butterham ES (Ed) Australian Pig Science Association, 1993, p 55-80.

[14] Barb CR, Hausman GJ, Houseknecht KL. Biology of leptin in the pig. Domest Anim Endocrinol 2001, 21: 297-317.

[15] Delavaud C, Ferlay A, Faulconnier Y, Bocquier F, Kann G, Chilliard Y. Plasma leptin concentration in adult cattle: effects of breed, adiposity, feeding level, and meal intake. J Anim Sci 2000, 80: 1317-1328. 